\title{
Iphimediidae of New Zealand (Crustacea, Amphipoda)
}

\author{
Charles Oliver COLEMAN ${ }^{1,3, *}$ \& Anne-Nina LÖRZ ${ }^{2,4}$ \\ ${ }^{1}$ Museum für Naturkunde, Leibniz Institute for Research on Evolution and Biodiversity, \\ Invalidenstraße 43, 10115 Berlin, Germany \\ * Corresponding author, e-mail: oliver.coleman@mfn-berlin.de \\ ${ }^{2}$ National Centre for marine Biodiversity \& Biosecurity, National Institute of Water and Atmospheric \\ Research, Private Bag 14901, Wellington 6021, New Zealand \\ E-mail: Anne-Nina.Loerz@niwa.co.nz \\ ${ }^{3}$ urn:1sid:zoobank.org:author:1EC18609-2D14-462B-8E59-B1CE40166FAF \\ ${ }^{4}$ urn:1sid:zoobank.org:author:9442484E-43A4-4383-A1A6-AE493087BCA1
}

\begin{abstract}
New Zealand species of Iphimediidae, Amphipoda, are revised. Based on new material from the Chatham Rise, east of New Zealand, two new species are described in detail: Labriphimedia meikae sp. nov. and Labriphimedia martinae sp. nov. A key to the six species belonging to three genera of New Zealand Iphimediidae is provided.
\end{abstract}

Key words. Crustacea, biodiversity, taxonomy, new species, Chatham Rise.

Coleman C.O. \& Lörz A.-N. 2013. Iphimediidae of New Zealand (Crustacea, Amphipoda). European Journal of Taxonomy 62: 1-18. http://dx.doi.org/10.5852/ejt.2013.62

\section{Introduction}

Over 100 species of Iphimediidae are known worldwide, yet only four were known from New Zealand waters. Many iphimediids have been recorded from Australian waters (Coleman \& Lowry 2006) to the northwest and in Antarctic waters (Coleman 2007) south of New Zealand. So it is expected that discovering more species of iphimediids in New Zealand is outstanding. Improved sampling techniques, using small meshed gear in the understudied deep sea, gained two species of iphimediids new to science described here in detail. The new species belong to the genus Labriphimedia K.H. Barnard, 1931; the two other genera present in New Zealand are Iphimedia Rathke, 1843 and Anisoiphimedia G.S. Karaman, 1980.

Anisoiphimedia is a dubious genus (Coleman \& Lowry 2006), that will be revised when more material becomes available. Anisoiphimedia haurakiensis (Hurley, 1954) from subtropical northern New Zealand was originally described in the genus Iphimedia. In contract, the species from cold southern New Zealand waters, Iphimedia spinosa (Hurley, 1954), was originally described as belonging to the genus Panoploea Thomson, 1880. 
Four of the five species of Labriphimedia are known from New Zealand waters. The species Labriphimedia hinemoa (Hurley, 1954) from shallow waters of the Hauraki Gulf, northern New Zealand, was originally described in the genus Maoriphimedia. Labriphimedia pulchridentata (Stebbing, 1883) was described from Heard Island at $136 \mathrm{~m}$ but recently found at the Macquarie Ridge, south of New Zealand in about $700 \mathrm{~m}$ depth (Lörz 2012). Labriphimedia vespucci Barnard, 1931 is known from the Falkland Islands at 105-115 m depth, and the two species new to science described herein were sampled on Chatham Rise east of New Zealand in 520-640 m depth.

For sampling location of all iphimediids in New Zealand waters see Fig. 1.

As the genus concept of the Iphimediidae is still under construction, a key directly from family level Iphimediidae to species level is provided.

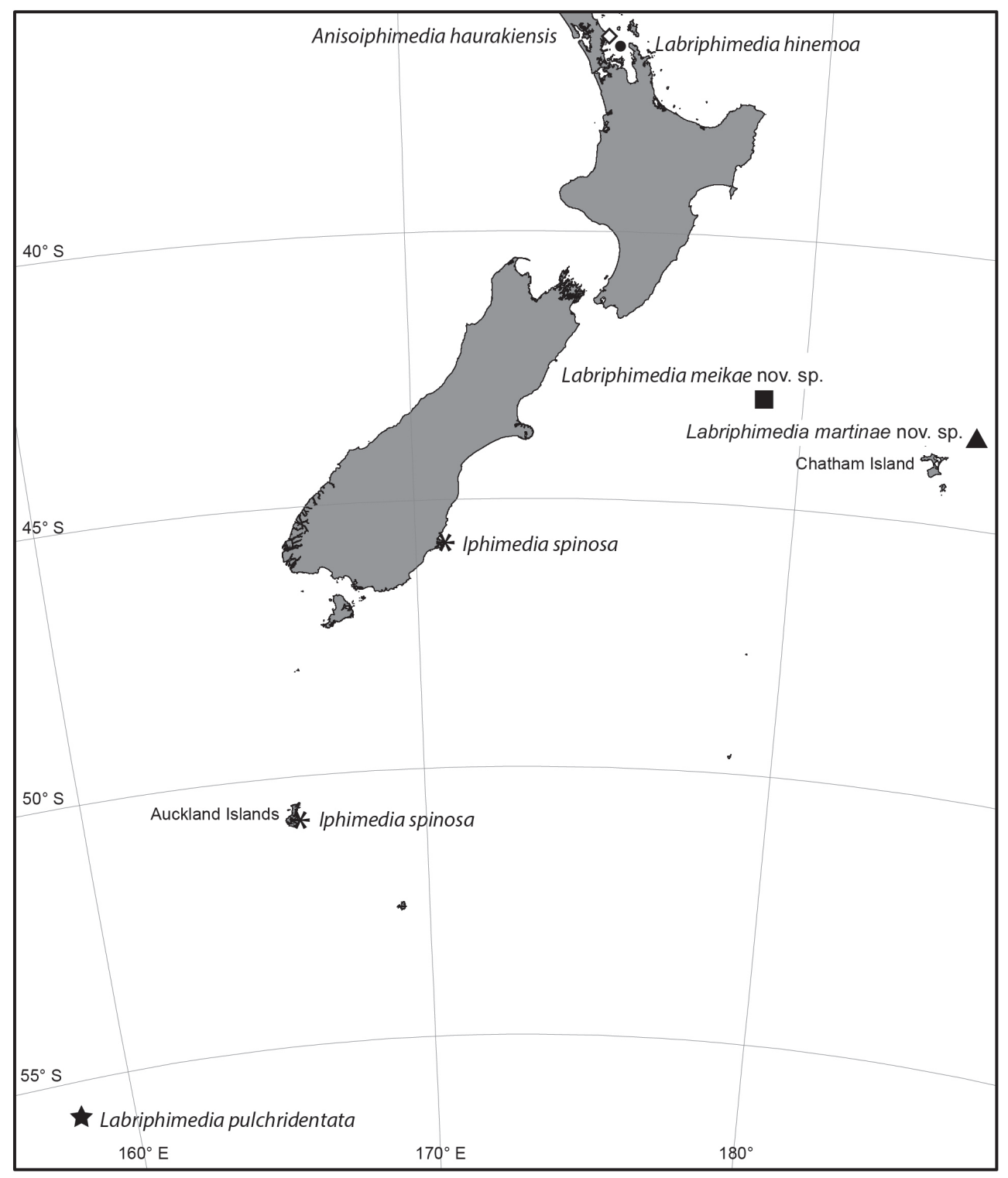

Fig. 1. Iphimediidae recorded from New Zealand, from subtropical to subantarctic waters. 


\section{Material and Methods}

The new iphimediid Amphipoda were collected during the Ocean Survey 20/20 with R/V Tangaroa on the Chatham Rise in 2007, east of New Zealand. The material was sampled via an epibenthic sledge with a $500 \mu \mathrm{m}$ mesh size. The iphimediids were fixed in $90 \%$ ethanol and later transferred into glycerol and mounted on slides for the preparation of the drawings. Pencil drawings were made with a camera lucida on a Leica M 205c dissecting microscope and a Leica DMLB compound microscope. The line drawings were made using the technique described in Coleman $(2003,2009)$. Length measurements were made along the outline of the animals, beginning at the tip of the rostrum to the end of the telson. The descriptions were generated from a DELTA database (Dallwitz 1993 onwards) of the Iphimedia species and related genera like Coboldus of the world, used in Coleman \& Lowry (2006). The DELTA text-output was modified to improve readability and adding characters that are relevant for the new taxa presented herein. The type material is deposited in the Invertebrate Collection of the National Institute of Water and Atmospheric Research (NIWA) in Wellington, New Zealand.

\section{Results}

\section{Key to New Zealand iphimediid species}

1 Coxa 5-7 posteriorly bicuspidate Labriphimedia pulchridentata Stebbing, 1883

- Coxa 5-7 posteriorly smooth or bearing single spine

2 Four pairs of spines dorsally 3

- Three pairs of spines dorsally, pleonite 3 not bearing paired spines

3 Coxa 1 ventrally acute; urosomite 2 dorsally smooth Labriphimedia meikae sp. nov.

- Coxa 1 ventrally rounded; urosomite 2 bearing dorsal carina Labriphimedia hinemoa (Hurley, 1954)

4 Pleonites 1-2 mid-dorsally smooth prior to paired spines; coxa 7 rounded .5

- Pleonites 1-2 with mid-dorsal pointy protrusion prior to paired teeth; coxa with 7 posteroventral margin pointed Labriphimedia martinae sp. nov.

5 Coxa 1 anterodistally rounded; coxa 6 posteriorly pointed Anisoiphimedia haurakiensis (Hurley, 1954)

- Coxa 1 anterodistally truncate; coxa 6 posteriorly rounded ..Iphimedia spinosa (Hurley, 1954)

Systematics

Amphipoda Latreille, 1816

Iphimediidae Boeck, 1871

Labriphimedia K.H. Barnard, 1931

Labriphimedia K.H. Barnard, 1931: 427 (type species: Labriphimedia vespuccii K.H. Barnard, 1931, original designation).

Maoriphimedia Hurley, 1954: 771 (type species: Maoriphimedia hinemoa Hurley, 1954, original designation). - Karaman \& Barnard, 1979: 111 (synonomy).

\section{Type species}

Labriphimedia vespucci K.H. Barnard, 1931

\section{Diagnosis}

Epistome short and broad. Upper lip wider than long, emarginated or elongate and tapering. 
Mandible tapering to a smooth spoon-shaped or spatulate apex, molar rudimentary, no spine row. Lower lip without inner lobes. Maxilla 1, palp 2 articles, stout or 1-articulate and minute. Maxilliped outer plate broad, palp slender, $2^{\text {nd }}$ article not medially produced.

\section{Species composition}

Labriphimedia hinemoa (Hurley, 1954)

Labriphimedia martinae sp. nov.

Labriphimedia meikae sp. nov.

Labriphimedia pulchridentata (Stebbing, 1883)

Labriphimedia vespucci K.H. Barnard, 1931

Labriphimedia meikae sp. nov.

Figs 2-6

urn:1sid:zoobank.org:act:BD138120-DFEB-4939-8848-7E6D79EE9B4C

\section{Material examined}

Holotype

§, 6 mm, NIWA 84598.

\section{Additional material}

Two paratypes of unknown sex, $5.2 \mathrm{~mm}$ and $5 \mathrm{~mm}$, NIWA 31826, same station data as holotype.

\section{Locus typicus}

NEW ZEALAND: TAN0705/251, 24 April 2007, 42॰59”45' S, 17859”44' E - 4259”28' S, 1790”19' E, 520-530 m.

\section{Etymology}

This species is named for Ms Meike Snyder, the dear aunt of the senior author.

\section{Description}

LENGTH. Based on male holotype, $6 \mathrm{~mm}$.

HEAD (Fig. 2A). Eyes reniform; rostrum only weakly curved; anterior margin with small rounded sculptured spine (which looks pointed in dorsal view), anteroventral corner with rounded lobe. Antenna 1 (Fig. 2B) peduncular article 1 with a long posteroventral spine reaching the distal margin of the peduncular article 2 and a shorter dorsal spine; peduncular article 2 with short spine; peduncular article 3 and flagellum unknown. Antenna 2 (Fig. 2D) peduncular article 2 with short rounded gland cone and longer bifid medial process; peduncular article 4 slightly drawn out laterally; peduncular article 5 and flagellum unknown. Upper lip (Fig. 2G) wider than long, emarginate. Mandibles (Fig. 2E) with smooth incisors and a spine-like lacinia mobilis on the left mandible (the right mandible apparently does not have a lacinia mobilis); palp 3-articulate, ratios of articles 1-3 1:1.4:1.2. Lower lip (Fig. 2C) inner lobes absent, distally rounded. Maxilla 1 (Fig. 3A) inner plate with 6 plumose setae on the inner margin; outer plate with 11 spine-like serrate setae; palp 2-articulate, well developed, longer than outer plate, with 9 apical setae. Maxilla 2 (Fig. 2F) inner plate slightly shorter and subequal in width compared to outer plate. Maxilliped (Fig. 3B-E) inner plate long, rectangular with slender plumose setae apically and 2 rows mediomarginally; outer plate with tapering apex, bordered with plumose setae; palp article 1 as long as articles 2 and 3 combined; article 2 weakly produced medially, not guarding along article 3 ; there may be an inconspicuous 4th article. 


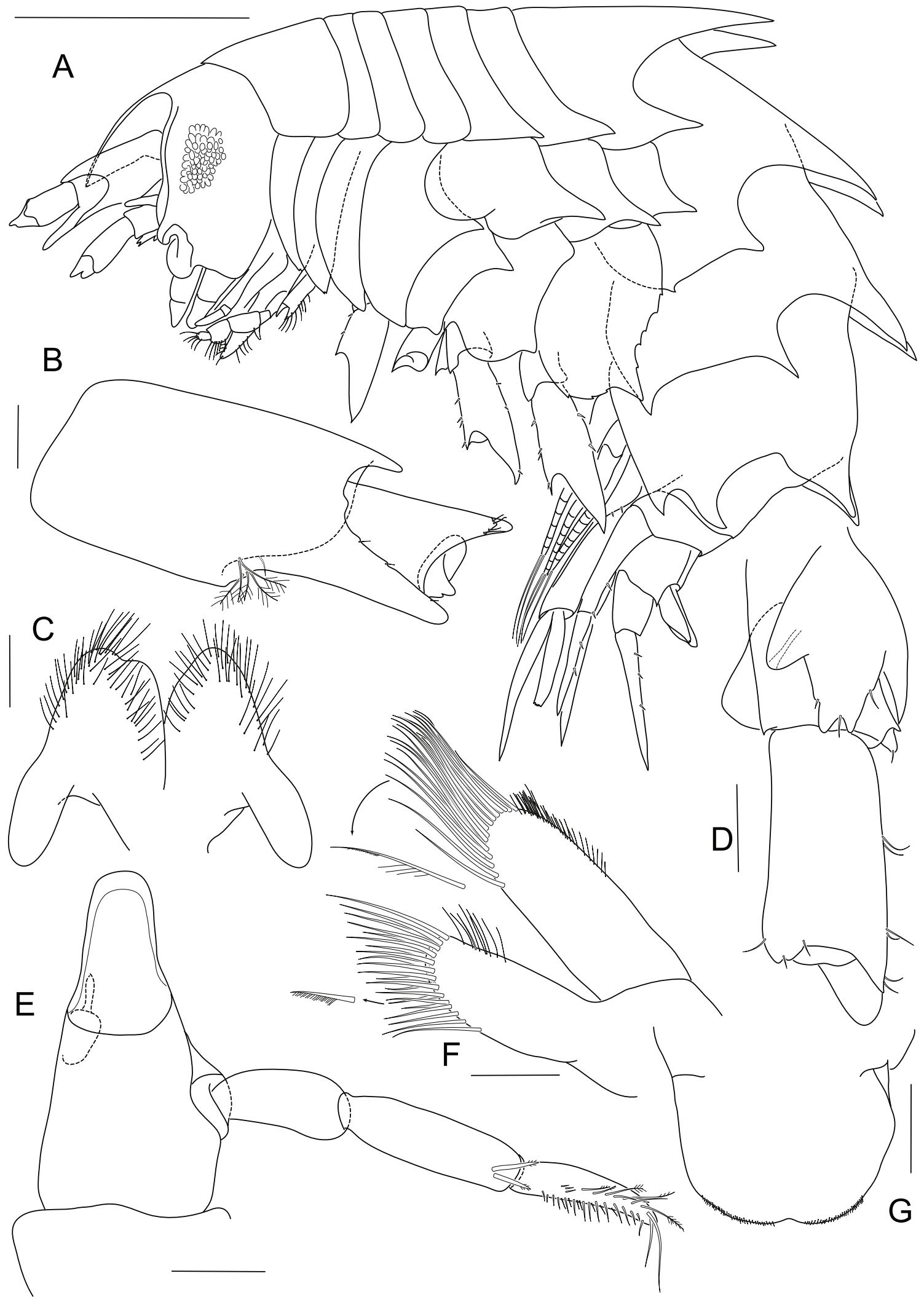

Fig. 2. Labriphimedia meikae nov. sp., holotype $\widehat{\partial}, 6 \mathrm{~mm}$, NIWA 84598. A. Habitus. B. Antenna 1, peduncular articles 1-2. C. Lower lip. D. Antenna 2, peduncular articles 1-4. E. Left mandible. F. Maxilla 2. G. Upper lip. Scale bars: $A=1 \mathrm{~mm}, \mathrm{~B}-\mathrm{G}=100 \mu \mathrm{m}$. 


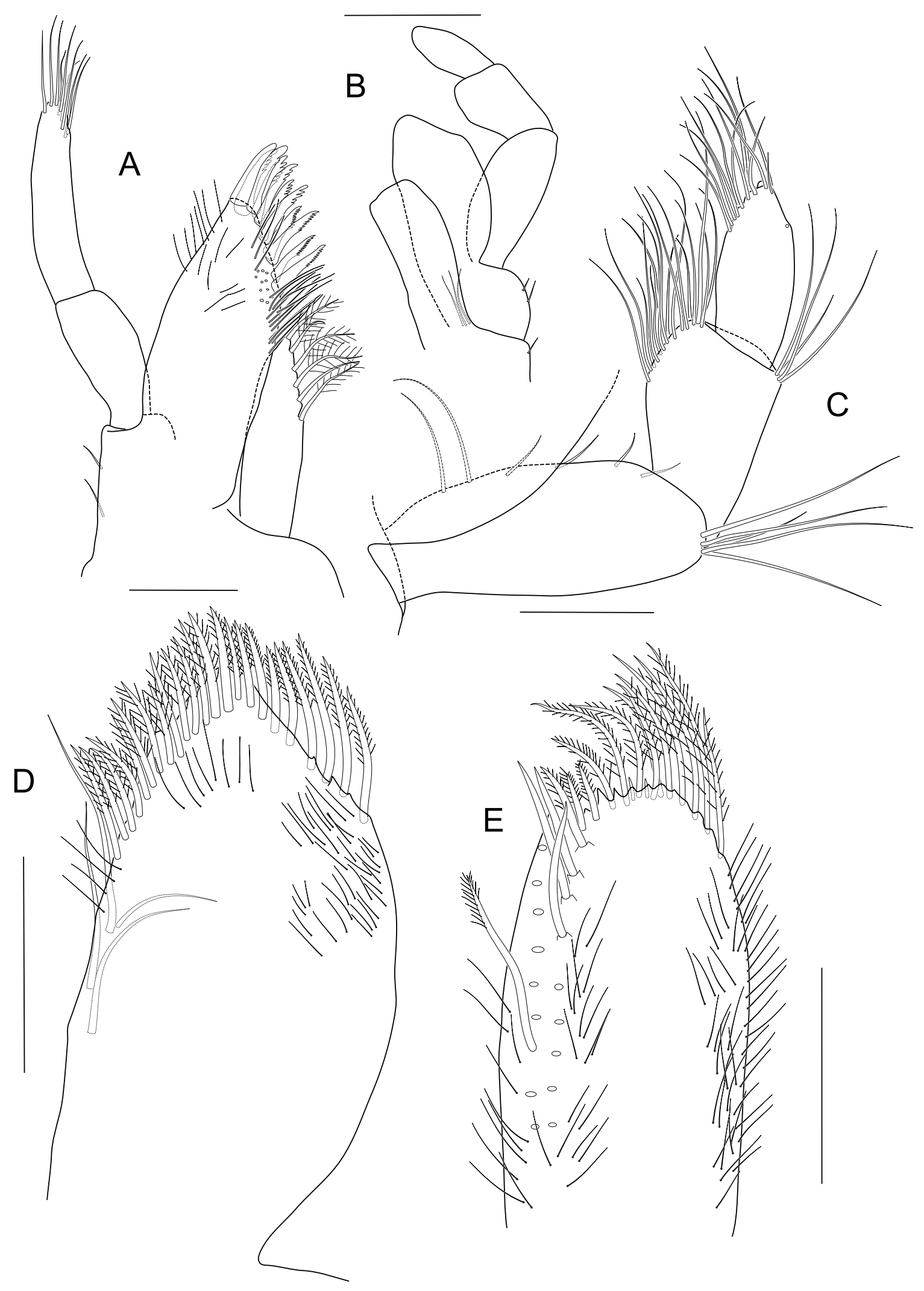

Fig. 3. Labriphimedia meikae nov. sp., holotype $\widehat{\jmath}, 6 \mathrm{~mm}$, NIWA 84598. A. Maxilla 1. B. Outlines of maxilliped. C. Palp of maxilliped. D. Outer plate of maxilliped. E. Inner plate of maxilliped. Scale bars: A, $C-E=100 \mu \mathrm{m}, \mathrm{B}=200 \mu \mathrm{m}$. 
Pereon (Fig 2A). Pereonite 1 enlarged, about 3-4 $\mathrm{x}$ as long as pereonite 2. Pereonites 5-7 with pointed and drawn out posteroventral angles. Pereonite 7 without mid-dorsal carina, dorsodistal margin with 2 large narrow pointed spines, space between spines wide. Gnathopod 1 (Fig. 4A) coxa ventrally acute, ventral and anterior margin smooth apart from 2 minute notches with microtrichs; basis longest; ischium

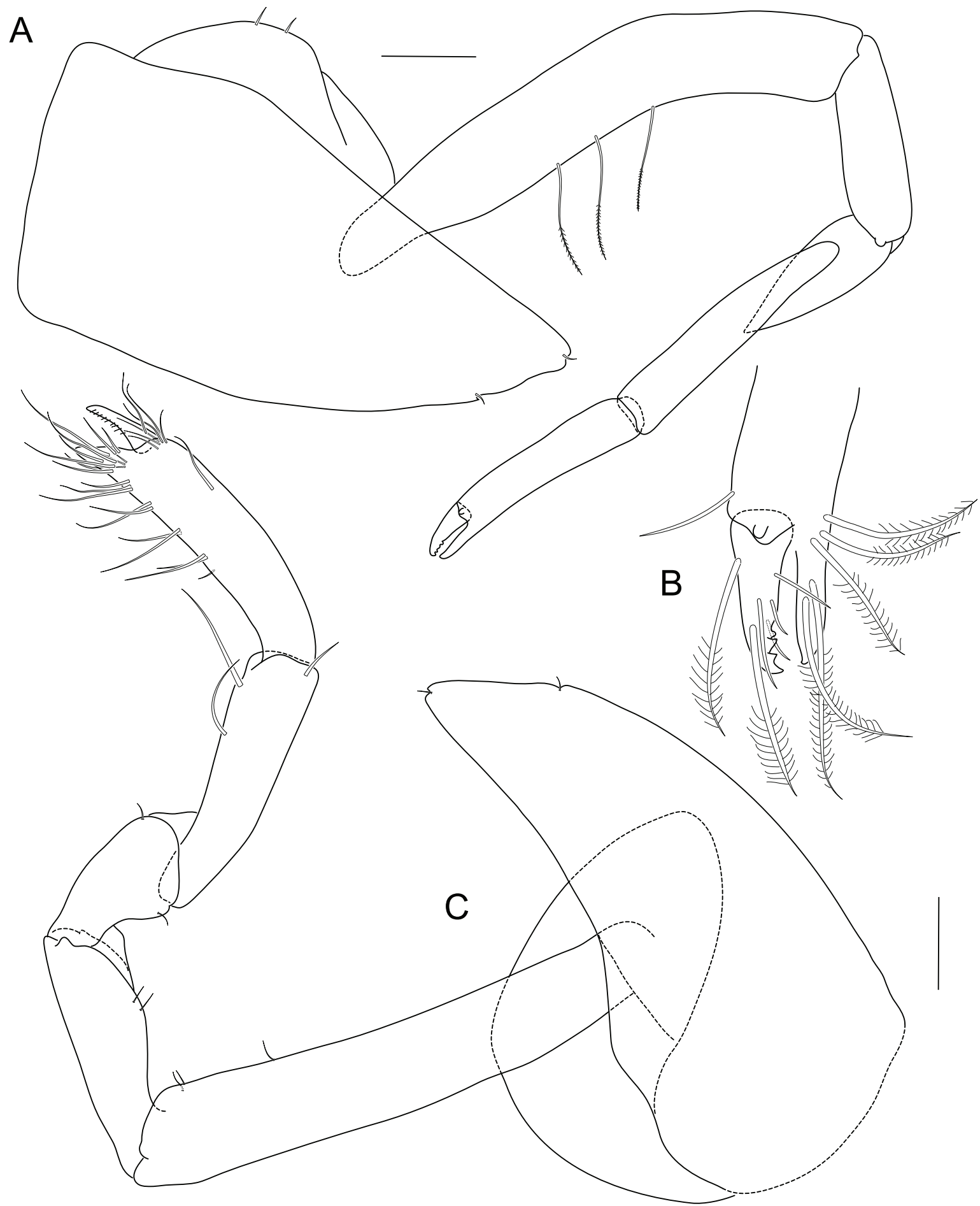

Fig. 4. Labriphimedia meikae nov. sp., holotype ${ }^{1}, 6 \mathrm{~mm}$, NIWA 84598. A. Gnathopod 1. B. Chela of gnathopod 1. C. Gnathopod 2. Scale bars: A, C $=100 \mu \mathrm{m}$. 
elongate, slightly longer than merus; carpus slightly longer than propodus; dactylus and propodus forming a chela, inner margin of dactylus serrate apically; setation, apart some setae on basis, only on chela. Gnathopod 2 (Fig. 4B) larger than gnathopod 1; coxa ventrally acute, ventral and anterior margin smooth apart from 2 minute notches with microtrichs; basis longest, ischium longer than merus; merus expanded distally; carpus and propodus subequal in length; propodus with groups of setae posteromarginally and apically; distal propodus extension wider than dactylus; chelate. Pereopod 3 (Fig. 5A) coxa longer than preceding coxae, posteroventrally acute, ventral margin apart from 2 minute

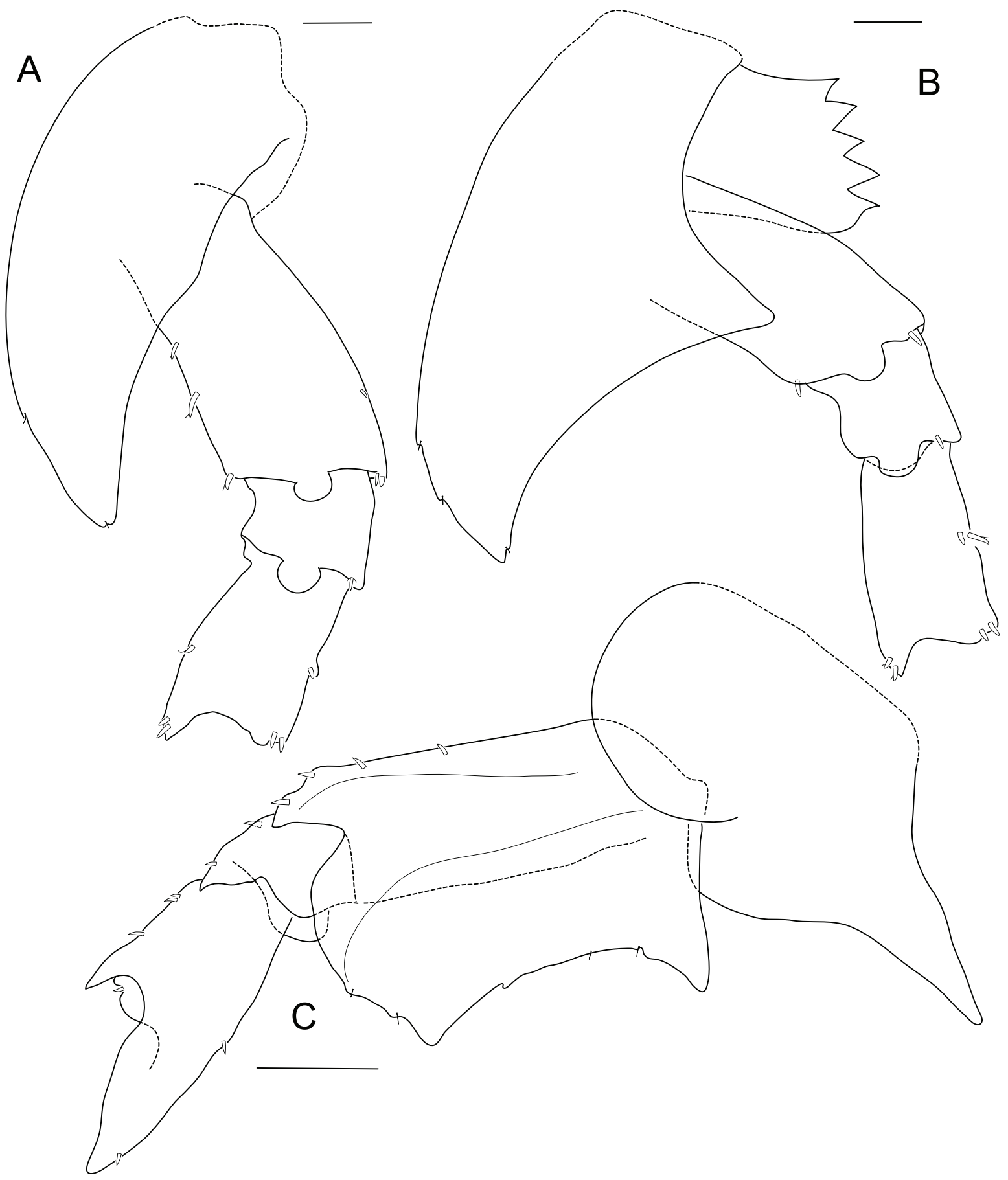

Fig. 5. Labriphimedia meikae nov. sp., holotype ${ }^{\lambda}, 6$ mm, NIWA 84598. A. Pereopod 3. B. Pereopod 4. C. Pereopod 5. Scale bars: A-B $=100 \mu \mathrm{m} . \mathrm{C}=200 \mu \mathrm{m}$. 


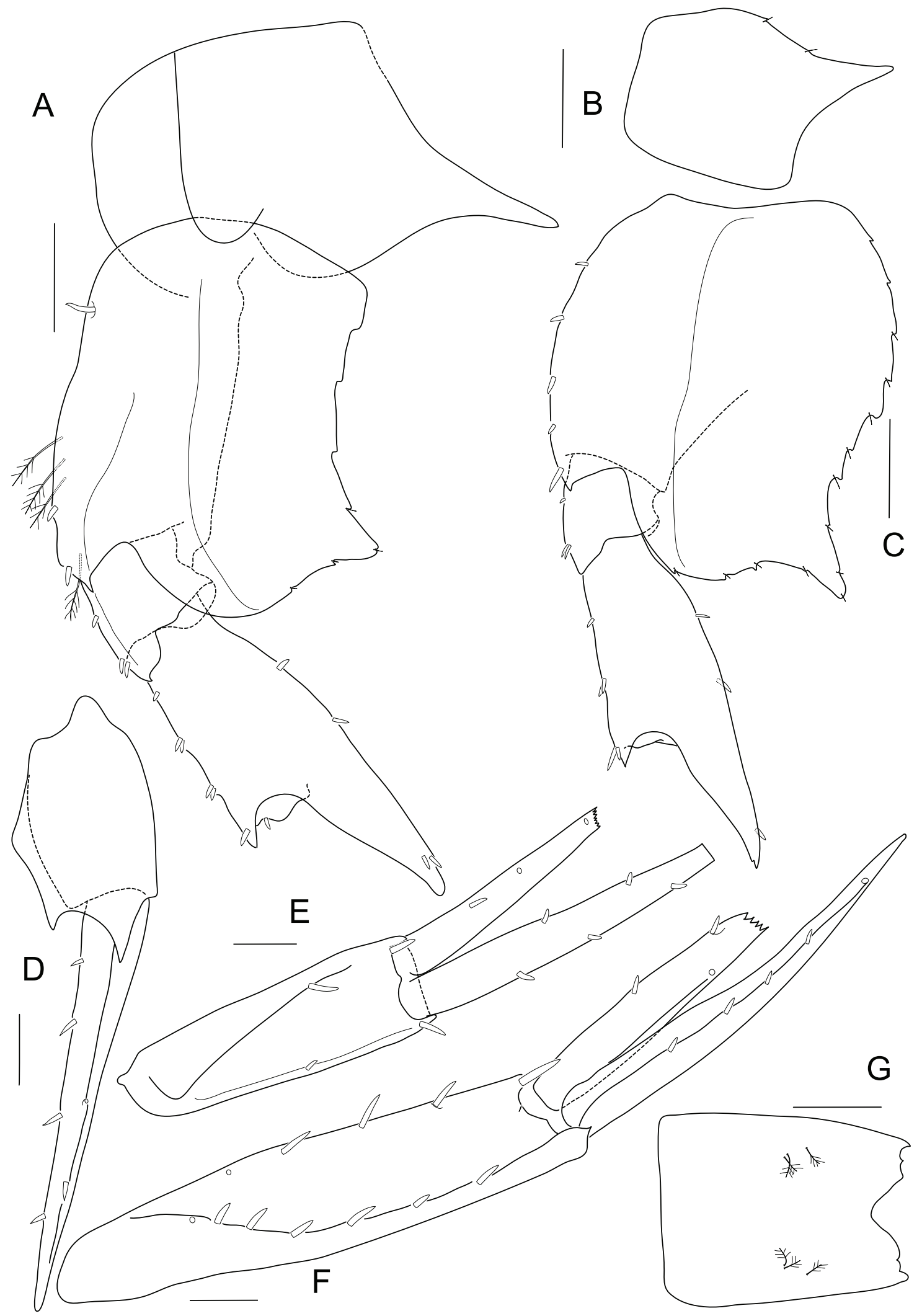

Fig. 6. Labriphimedia meikae nov. sp., holotype $0,6 \mathrm{~mm}$, NIWA 84598. A. Pereopod 6. B. Coxa of pereopod 7. C. Basis to merus of pereopod 7. D. Uropod 3. E. Uropod 2. F. Uropod 1. G. Telson. Scale bars: A-C $=200 \mu \mathrm{m}, \mathrm{D}-\mathrm{G}=100 \mu \mathrm{m}$. 
notches with microtrichs smooth; basis and ischium with rounded lobe on apical margin. Pereopod 4 (Fig. 5B) coxa pointed distally and posteromarginally, ventral margin smooth apart from some minute notches with microtrichs; basis and ischium with rounded lobe on apical margin. Pereopod 5 (Fig. 5C) coxa with long pointed posteroventral spine; basis posterior margin with 2 spines: posterodorsal spine pointed, posteroventral corner subquadrate; posterior margin weakly serrate; ischium anterodistally pointed; merus posteroventral lobe elongate; carpus to dactylus unknown. Pereopod 6 (Fig. 6A) of similar shape as pereopod 5 , but basis wider with a pointed posteroventral corner and bearing an angular posterodorsal process. Pereopod 7 (Fig. 6B-C) coxa small with pointed posteromarginal spine; basis posteroventrally with spine, directed ventrally, posterior margin weakly serrate; merus posteroventral lobe elongate.

Pleon (Fig. 2A). Pleonite 1 without mid-dorsal carina, with 2 large, pointed spines, space between spines widely excavate, similar to the arrangement on pereonite 7. Epimeron 1 posterior margin with 1 mid-lateral spine, posteroventral corner with short point. Pleonite 2 without mid-dorsal carina; with 2 large, pointed spines, space between spines wide. Epimeron 2 posterior margin with 1 mid-lateral spine, posteroventral corner pointed. Pleonite 3 without mid-dorsal carina; dorsodistal margin with 2 straight spines, shorter than those on pereonite 7 and pleonites 1-2. Epimeron 3 posterior margin with 1 well developed lateral, smooth spine, posteroventral corner produced into smooth spine. Urosomite 1 longest, smooth. Urosomite 2 shortest. Telson (Fig. 6G) emarginate.

\section{Distribution}

Chatham Rise, New Zealand (South-western Pacific), 520-530 m.

Labriphimedia martinae sp. nov.

Figs 7-11

urn:1sid:zoobank.org:act:D8ED7489-8474-4E50-9856-27119A69E933

\section{Material examined}

\section{Holotype}

ग, $6.5 \mathrm{~mm}$, NIWA 84743 .

\section{Locus typicus}

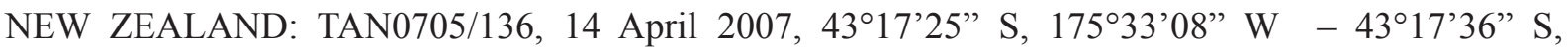
$175^{\circ} 33^{\prime} 47^{\prime \prime}$ E, 638-644 m.

\section{Etymology}

This species is named for the amiable Ms Martine Willcox, the mother of the son-in-law of the senior author.

\section{Description}

LeNGTH. Based on male holotype, $6.5 \mathrm{~mm}$.

HEAD (Fig. 7A). Eyes ovate; rostrum strongly curved; anterior margin with angular spine, anteroventral corner with an acute long narrow spine. Antenna 1 (Fig. 7C-D) peduncular article 1 with a long distomedial spine and a small anterodistal spine; peduncular article 2 with longer dorsal and small spine, with an anterodistal spine; accessory flagellum present, accessory flagellum 1-articulate; article 3 with anterodistal process; article 4 subequal to 3. Antenna 2 (Fig. 7G) articles 2 and 3 serrate distomedially. Mouthparts arranged in a cone. Upper lip (Fig. 7B) tapering distally, apex asymmetrical. Mandibular body (Fig. 7E, F, I, H) tapering distally; incisor not dentate; lacinia mobilis on right side rather stout; 


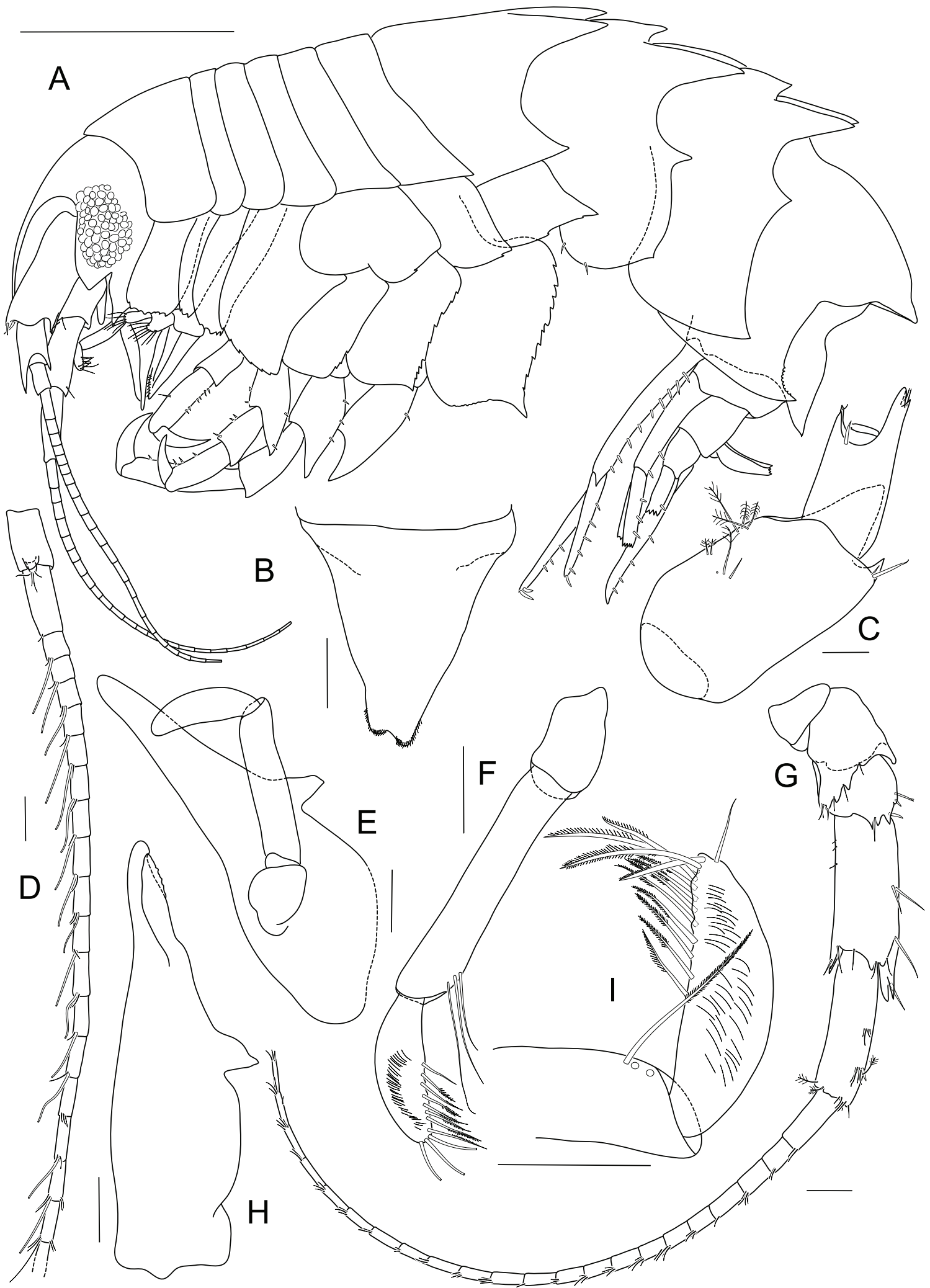

Fig. 7. Labriphimedia martinae nov. sp., holotype ${ }_{0}, 6.5 \mathrm{~mm}$, NIWA 84743 . A. Habitus. B. Upper lip. C. Antenna 1 peduncular articles 1-2. D. Peduncular article 3 and flagellum of antenna 1. E. Left mandible, setation of palp omitted. F. Right mandibular palp. G. Antenna 2. H. Right mandibular body. I. Apical mandibular palp article. Scale bars: $A=1 \mathrm{~mm}, \mathrm{~B}-\mathrm{G}=100 \mu \mathrm{m}$. 


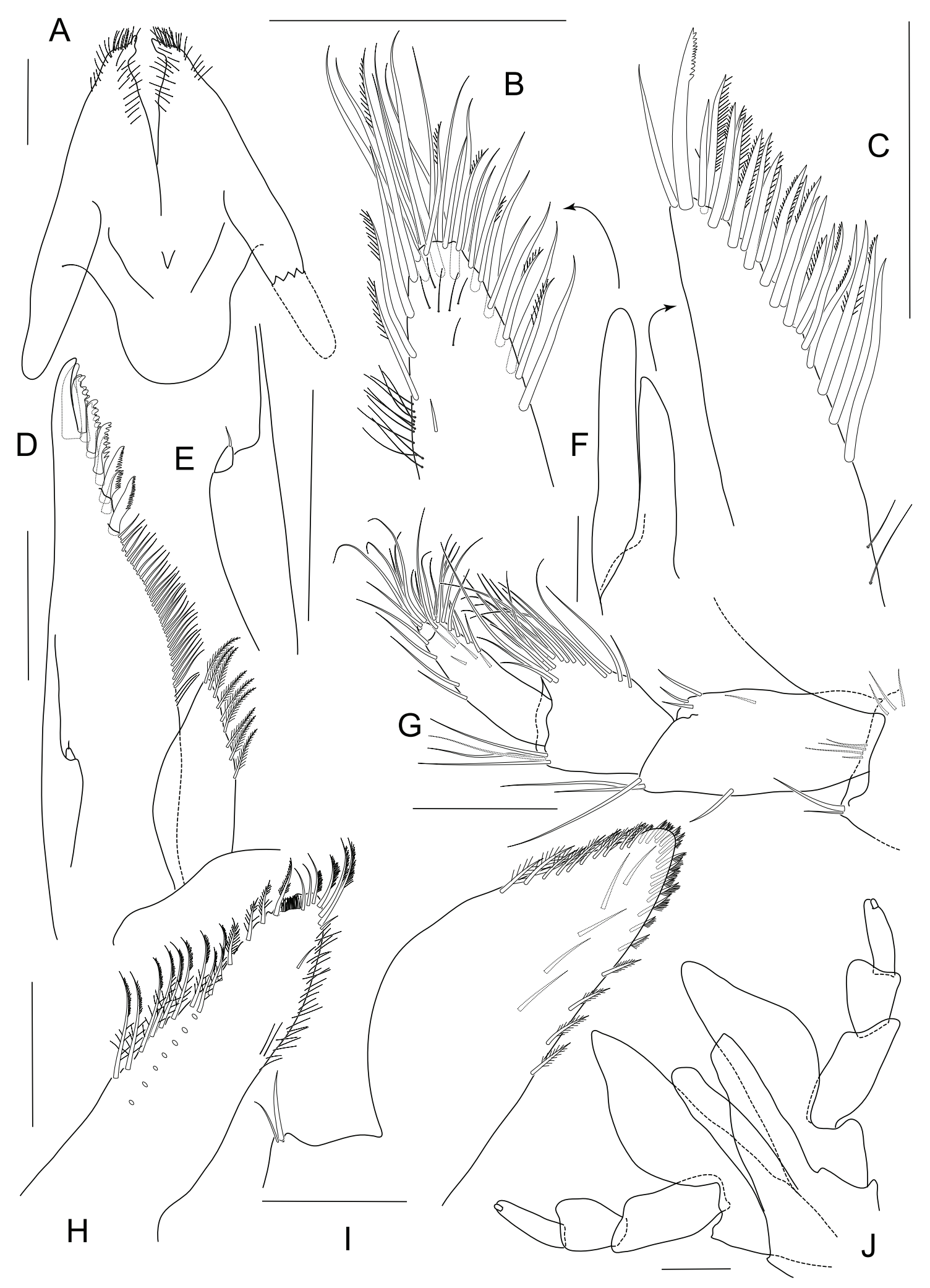

Fig. 8. Labriphimedia martinae nov. sp., holotype $\widehat{\jmath}, 6.5 \mathrm{~mm}$, NIWA 84743 . A. Lower lip. B. Outer plate of maxilla 2. C. Inner plate of maxilla 2. D. Left maxilla 1. E. Palp of right maxilla 1. F. Outlines of maxilla 2. G. Palp of maxilliped. H. Inner plate of maxilliped. I. Outer plate of maxilliped. J. Outline of maxillipeds. Scale bars: A-J $=100 \mu \mathrm{m}$. 


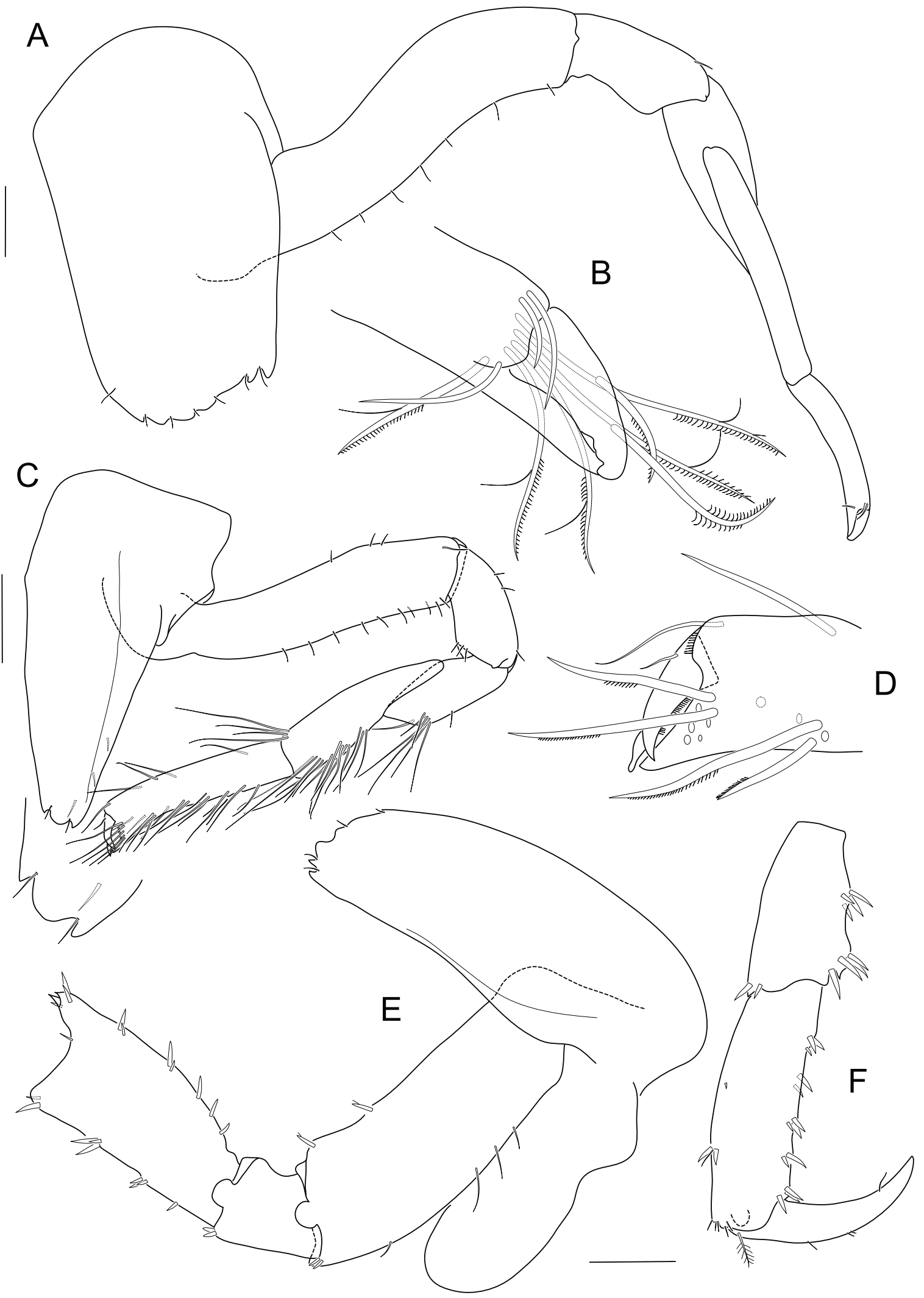

Fig. 9. Labriphimedia martinae nov. sp., holotype $\delta^{\lambda}, 6.5 \mathrm{~mm}$, NIWA 84743. A. Gnathopod 1. B. Chela of gnathopod 1. C. Gnathopod 2. D. Chela of gnathopod 2. E. Pereopod 3. F. Presumed carpus to dactylus of pereopod 3. Scale bars: A, C, E-F $=100 \mu \mathrm{m}$. 


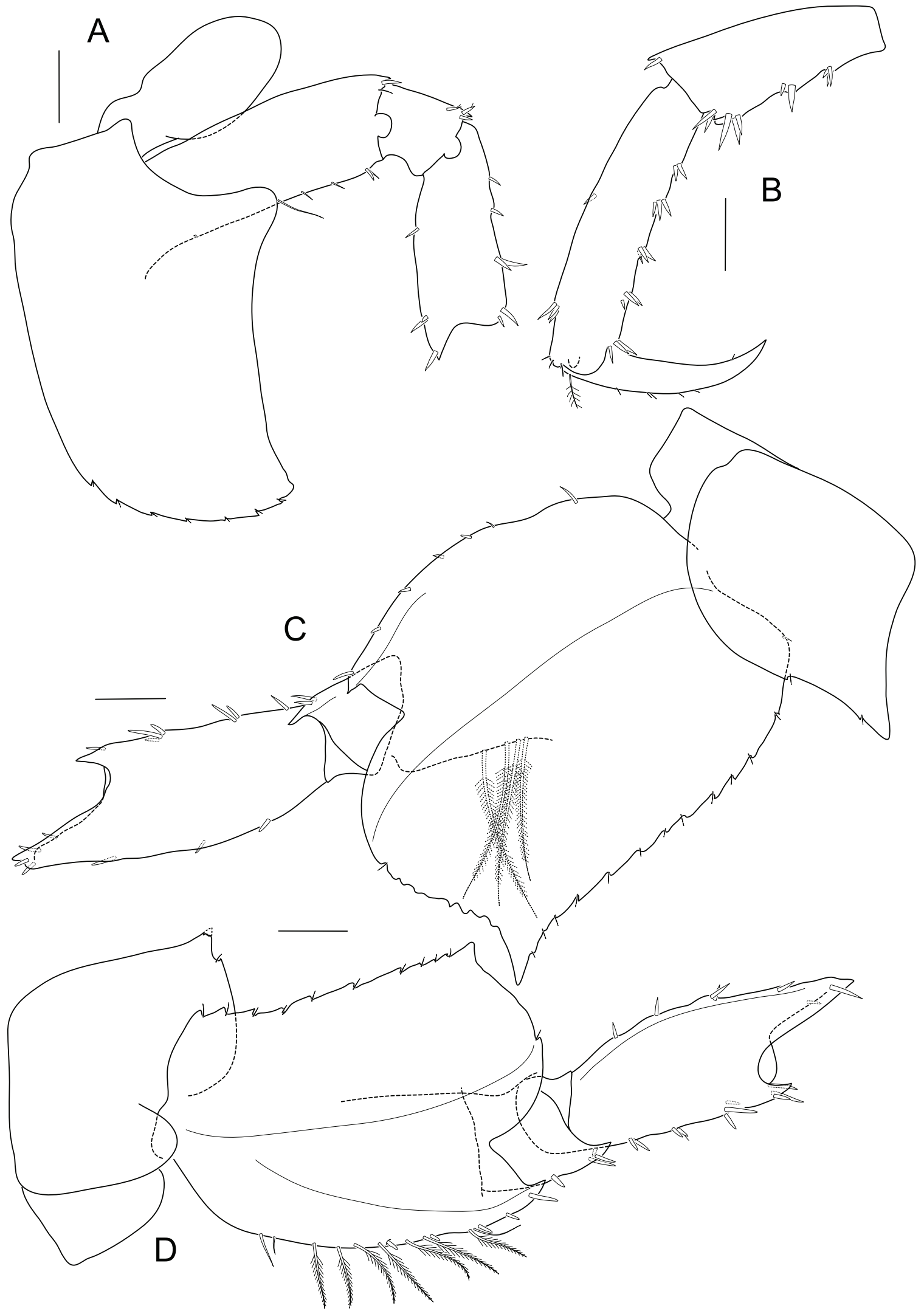

Fig. 10. Labriphimedia martinae nov. sp., holotype $\widehat{\delta}, 6.5 \mathrm{~mm}$, NIWA 84743 . A. Pereopod 4. B. Presumed carpus to dactylus of pereopod 4. C. Pereopod 7. D. Pereopod 6. Scale bars: A-D $=100 \mu \mathrm{m}$. 
molar not triturative, but protruding; palp 3 articulate, ratios of articles 1-3 1:2.75:1.5. Lower lip (Fig. 8A) inner lobes absent; lobes tapering distally into pointed apex. Maxilla 1 (Fig. 8D-E) palp 1-articulate, much shorter than outer plate, very small scale with an apical seta. Maxilla 2 (Fig. 8B-C, F) inner lobe considerably shorter than outer. Maxilliped (Fig. 8G-J) inner lobe elongate, surpassing the distal margin of 1st palp article, with setae on the apex and 2 rows of setae along the medial margin; outer plate

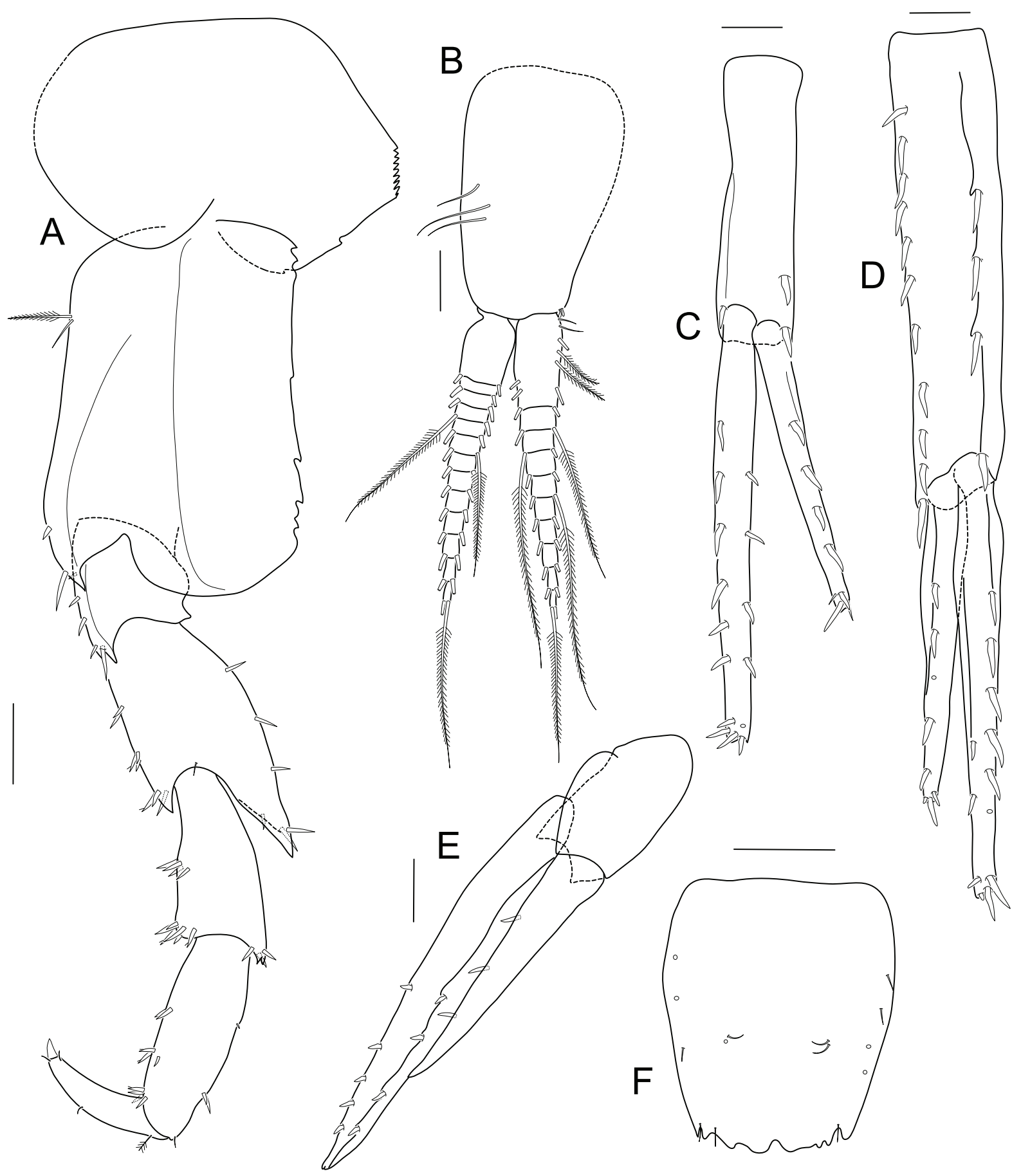

Fig. 11. Labriphimedia martinae nov. sp., holotype $\widehat{\phi}, 6.5 \mathrm{~mm}$, NIWA 84743. A. Pereopod 5. B. Pleopod 1. C. Right uropod 2. D. Uropod 1. E. Uropod 3. F. Telson. Scale bars: A-F $=100 \mu \mathrm{m}$. 
tapering distally, bordered with plumose setae apically; palp consisting of 3 long articles and 1 minute distolateral article; 2nd palp article expanded distomedially.

Pereon (Fig. 7A). Pereonite 1 enlarged, 3-4 $\mathrm{x}$ as long as pereonite 2. Pereonites 5-6 posteroventral angle acute; that of pereonite 7 pointed and drawn out. Pereonite 7 without mid-dorsal carina, dorsodistal margin with 2 large pointed spines, space between spines widely excavate, with 1 posteroventral spine. Gnathopod 1 (Fig. 9A-B) coxa subrectangular, ventrally truncated and serrate; basis slightly longer than coxa; carpus somewhat longer than propodus, both carpus and propodus narrow; setation restricted to anterior margin of basis and region of chela. Gnathopod 2 (Fig. 9C-D) slightly shorter than gnathopod 1; coxa tapering, ventrally truncated, ventral margin with 2 notches with microtrichs; carpus and propodus subequal in length, strongly setose; Pereopod 3 (Fig. 9E-F) coxa ventrally rounded, ventral margin weakly serrate; basis and ischium with rounded lobe distomarginally. Pereopod 4 (Fig. 10A-B) coxa wide, apically rounded, with angular posteroventral corner, ventral margin serrate; posterior margin with rounded lobe; basis and ischium with rounded lobe distomarginally. Pereopod 5 (Fig. 11A) coxa wider than long, bilobate, posterior margin pointed; basis subrectangular, posterior margin straight, weakly serrate, posteroventral corner subquadrate, anterodistal angle pointed; ischium anterodistal angle pointed; merus drawn out posterodistally; carpus expanded distally, slightly shorter than propodus; dactylus not curved much, with small unguis. Pereopod 6 (Fig. 10D) coxa bilobate, anterior lobe shorter, with posteroventral spine; basis anterodistally pointed, posterodorsal corner subquadrate, posterior margin weakly serrate, posteroventral corner with small spine; ischium and merus as for pereopod 5. Pereopod 7 (Fig. 10C) coxa with posteroventral spine; basis anterodistally pointed, posterodorsal corner rounded, posterior margin weakly serrate, posteroventral corner with large spine; merus and carpus as for pereopod 5 .

Pleon (Fig. 7A). Pleonite 1 with a low, truncated mid-dorsal carina with a small posterior point, with 2 large, pointed spines, space between spines wide. Epimeron 1 posterior margin with 1 mid-lateral spine, posteroventral corner acutely with short point. Pleonite 2 with a low truncated mid-dorsal carina with a small posterior point, dorsodistal margin with 2 large, pointed spines, space between spines wide. Epimeron 2 posterior margin with 1 mid-lateral spine, posteroventral corner pointed. Pleonite 3 with a broadly rounded, large mid-dorsal carina. Epimeron 3 posterior margin without well developed lateral spines, posteroventral corner produced into 1 smooth spine, its dorsal part minutely serrate. Urosomite 1 large with broadly rounded, large mid-dorsal carina with a shallow depression. Urosomite 2 shortest, smooth. Telson (Fig. 11F) truncate, with several small notches along the distal margin.

\section{Distribution}

Chatham Rise, New Zealand (South-western Pacific), 638-644 m.

\section{Discussion}

The classification of the two new species turned out to be difficult. It was clear that they were new species after comparison with all known iphimediid species, but it was very difficult to decide in which genus they belong. The systematics of iphimediids is mostly based on the spination of the body, the coxae and the bases of the appendages, and on the mouthpart morphology, more specifically the shape and dentation of the incisor, and the development of the palps of maxilla 1 and the maxilliped.

The mandible of L. meikae sp. nov. is similar to that of Labriphimedia hinemoa (Hurley, 1954). In both species the incisor is toothless and apically rounded and medially excavate. Also some other characters on the mouthparts correspond in the shapes: of antenna 1 peduncular article 1, upper lip, lower lip, maxilla 1 and maxilliped. The heads of both species are very different: L. meikae sp. nov. has a weakly curved rostrum (vs. strongly curved), large eyes (vs. small), anterior head margin rounded in lateral view (vs. pointed) and the ventral head margin with a sculptured rounded lobe (vs. longer subacute lobe). 
The coxal plates 1-4 are not so pointed ventrally in L. hinemoa. The shapes of the pereopod 5-7 bases are similar, but the anterior margin in L. meikae sp. nov. is not so densely covered with setae as in $L$. hinemoa.

Both species share the 4 pairs of mid-dorsal spines, but the shape differs. In L. meikae sp. nov. the dorsal spines are slender seen from laterally and have a wide u-shaped excavation seen from dorsally. However, in L. hinemoa the spines are rather wide from lateral aspect and form a v-shaped narrow slit in the dorsal view. The telson of $L$. hinemoa appears to be deeper notched and has subacute lobes compared to L. meikae sp. nov., where the telson lobes are truncate.

Labriphimedia martinae sp. nov. is more difficult to classify. This species has some superficial resemblance to Labriphimedia vespucci K.H. Barnard, 1931 in the shape of coxae 1-4 and in the prominent carina on pleonite 3 and urosomite 1, which is, however, notched in lateral view in the latter species. Also, both species have a serrate margin of epimeron 3 just dorsal of the posteroventral angle, but in $L$. vespucci there is an additional spine on the posterior margin. Compared to L. vespucci, in L. martinae sp. nov. the paired dorsal spines on pleonite 3 are missing, the eyes are much larger, covering more than half of the head (vs. less than half) and the mouthparts are very different: the mouthparts are arranged into a pointed bundle, upper lip, mandibles and lower lip are pointed, also maxilla 1 is elongate, but its palp is reduced to a small scale. In $L$. vespucci, however, the mouthparts do not seem to be elongate, the upper lip is much broader than long and maxilla 1 looks similar to that of L. meikae sp. nov. (not elongate, with a long 2-articulate palp). A shortened palp of maxilla 1 is known in many iphimediid species, especially in the genus Iphimedia, but there the palp is 2-articulate. A 1-articulate palp of maxilla 1 within Iphimediidae is known in the genus Coboldus Krapp-Schickel, 1974 and we were initially attracted by the idea that L. martinae sp. nov. could be classified in the genus Coboldus. In favour of Coboldus would count the shortened 1-articulate palp of maxilla 1, the pointed mouthpart bundle and the elongate 2nd article of the mandibular palp, which some species have (e.g., C. laetifucatus Just, 1990). However, other characteristics of Coboldus are not present in L. martinae: a strongly produced 2nd article of the maxillipedal palp guarding along article 3, the absence of carinae on pleonites 1-3 and urosomite 1 and the presence of a lateral spine on the posterior margin of epimeron 3. It may be that there is some phylogenetic connection between both genera, Coboldus and Labriphimedia, which we hope to resolve in a future project.

The genus Labriphimedia is so far only known from the southern hemisphere, and four of the now known five species of Labriphimedia occur in New Zealand waters.

\section{Acknowledgements}

We like to thank Ms Makena Löhr who did several pencil drawings of appendages of Labriphimedia martinae sp. nov. Erika MacKay (NIWA) created the map. The material was supplied by the NIWA Invertebrate Collection and collected during the Ocean Survey 20/20 Chatham/Challenger Biodiversity and Seabed Habitat Project, jointly funded by the New Zealand Ministry of Fisheries, Land Information New Zealand, NIWA, and the Department of Conservation. The second author was supported by NIWA through Coast and Oceans Research Programme 2, Biodiversity \& Biosecurity, taxonomy project COBR1402.

\section{References}

Coleman C.O. 2003. "Digital inking": How to make perfect line drawings on computers. Organism Diversity and Evolution 3, Electronic Supplement 14: 1-14. (http://senckenberg.de/odes/03-14.htm). http://dx.doi.org/10.1078/1439-6092-00081 
Coleman C.O. 2007. Synopsis of the Amphipoda of the Southern Ocean; Volume 2: Acanthonotozomellidae, Amathillopsidae, Dikwidae, Epimeriidae, Iphimediidae, Ochlesidae and Vicmusiidae. Bulletin de l'institut Royal des Sciences Naturelles de Belgique, Biologie 77, Supplement 2: 1-142.

Coleman C.O. 2009. Drawing setae the digital way. Zoosystematics and Evolution 85 (2): 305-310. http://dx.doi.org/10.1002/zoos.200900008

Coleman C.O. \& Lowry J.K. 2006. Australian Iphimediidae (Crustacea: Amphipoda). Organisms Diversity \& Evolution 6, Electronic Supplement 9: 1-44. http://www.senckenberg.de/odes/06-09.htm

Dallwitz M.J. 1993 onwards. Applications and Documentation of the DELTA System. http://deltaintkey.com

Lörz A.N. 2012. First records of Epimeriidae and Iphimediidae (Crustacea, Amphipoda) from Macquarie Ridge, with description of a new species and its juveniles. Zootaxa 3200: 49-60.

Manuscript received: 1 August 2013

Manuscript accepted: 27 September 2013

Published on: 6 November 2013

Topic editor: Rudy Jocqué

Desk editor: Kristiaan Hoedemakers

Printed versions of all papers are also deposited in the libraries of the institutes that are members of the EJT consortium: Muséum National d'Histoire Naturelle, Paris, France; National Botanic Garden of Belgium, Meise, Belgium; Royal Museum for Central Africa, Tervuren, Belgium; Natural History Museum, London, United Kingdom; Royal Belgian Institute of Natural Sciences, Brussels, Belgium; Natural History Museum of Denmark, Copenhagen, Denmark. 